\title{
Antioxidative and antibacterial activities of phenolic compounds from Ficus sur Forssk. and Ficus sycomorus L. (Moraceae) : potential for sickle cell disease treatment in Burkina Faso
}

\author{
Alphonsine RAMDE-TIENDREBEOGO ${ }^{1}$, André TIBIRI ${ }^{1,2^{*}}$, Adama HILOU ${ }^{1}$, \\ Marius LOMPO ${ }^{2}$, Hassanata MILLOGO-KONE ${ }^{2}$, Odile Germaine NACOULMA ${ }^{1}$ and \\ Innocent Pierre GUISSOU ${ }^{2,3}$
${ }^{1}$ Laboratoire de Biochimie et de Chimie Appliquées (LABIOCA)/Unité de Formation et de Recherche en Sciences de la Vie et de la Terre (UFR/SVT), Université de Ouagadougou, 09 BP 848 Ouagadougou 09, Burkina Faso. la Santé (MEPHATRA-PH/IRSS), 03 BP 7192 Ouagadougou 03, Burkina Faso.
${ }^{3}$ Laboratoire de Pharmacologie-Toxicologie/Unité de Formation et de Recherche en Sciences de la Santé (UFR/SDS), Université de Ouagadougou, 03 BP 7021 Ouagadougou 03, Burkina Faso.
*Corresponding Author; Tel: (+226)70262962; E-mail: tibiriandre@gmail.com \\ ${ }^{2}$ Département de Médecine et Pharmacopée Traditionnelles-Pharmacie/Institut de Recherche en Sciences de
}

\begin{abstract}
Ficus sur and Ficus sycomorus, two medicinal species used in Burkinabe traditional medicine for the treatment of sickle cell disease were investigated. The determination of total phenolic and tannins contents, using the method of Folin-Ciocalteu (FCR), indicate values significantly ( $\mathrm{p}<0.05$ ) higher in extracts of Ficus sycomorus compared to those of Ficus sur, with respective values of $336.80 \pm 0.80 \mathrm{mg} \mathrm{TAE} / \mathrm{g}$ of extract and $203.74 \pm 0.9 \mathrm{mg}$ TAE$/ \mathrm{g}$ of extract against $247.00 \pm 0.52 \mathrm{mg}$ TAE$/ \mathrm{g}$ of extract and $120.8 \pm 0.83 \mathrm{mg} \mathrm{TAE} / \mathrm{g}$ of extract. Similarly, using the method of 1,1-diphenyl-2-picrylhydrazyl (DPPH), the results of the analysis indicate that extracts of Ficus sycomorus produce the highest antiradical activity with $\mathrm{IC}_{50}$ value of $9.60 \pm 0.02$ $\mu \mathrm{g} / \mathrm{mL}$ against $31.83 \pm 0.55 \mu \mathrm{g} / \mathrm{mL}$ for Ficus sur. The $\mathrm{IC}_{50}$ value of quercetin, used as reference antioxidant, was of $4.6 \pm 0.08 \mu \mathrm{g} / \mathrm{mL}$. The latex of Ficus sycomorus presented the lowest minimum inhibitory concentrations (MIC) against Staphylococcus aureus and Escherichia coli, with respective values of 0.13 $\mathrm{mg} / \mathrm{mL}$ and $0.25 \mathrm{mg} / \mathrm{mL}$. The difference in phenolic content could explain the difference in biological activity between the two Ficus species.
\end{abstract}

(C) 2012 International Formulae Group. All rights reserved.

Keywords: drepanocitosis, radical scavenging, tannins, flavonoids, medicinal plants.

\section{INTRODUCTION}

Sickle cell disease is an inherited disorder linked to mutations in the hemoglobin gene. Several complications, including chronic haemolysis, anemia and severe acute vaso-occlusive injuries were found as due to this disease (Girot et al., 2003). One of the main characteristics of this pathology is producing a huge amount of free radicals, leading to a severe oxidative stress (Sess et al., 1998). Usually, many infections (e.g. due to Staphylococcus aureus, 
Salmonella sp. and Escherichia coli) are also associated with this disease, as consequences of the complications listed above (Schmugge et al., 2008). Sickle cell disease is the most common genetic hemoglobin disorders encountered in Africa. In Burkina Faso, more than $25 \%$ of the population has a mutation in hemoglobin and about $3 \%$ of children have major sickle cell syndrome (MSS) of homozygous (SS, S indicates a mutation of valine) or composite heterozygous (SC, C indicates a mutation of lysine) (CID, 2010).

Being an endemic disease, and specifically present in tropical countries, sickle cell disease is not taken into account in research programs of global pharmaceutical companies, due to the fact that related trading profits seem weak. This is a "neglected" disease, in terms of scientific research. The few modern drugs available are very expensive for African patients. Being faced for centuries to this disease, African traditional medicine has had to deal with thanks to medicinal plants. Indeed, medicinal recipes are often used in Africa for the management of the disease, to mitigate, for example, recurrent inflammation (pain, fever, and edema), anemia and frequent infections. Until today, however, only few scientific data on these medicinal plants are available. Then there is an urgent need to investigate, in this sense, the rich African flora.

An ethnobotanical survey, conducted in the region of the central plateau of Burkina Faso showed that the two species, Ficus sur Forssk. and Ficus sycomorus L., are used in folk medicine for the treatment of sickle cell disease. Ficus sur (called womsèèga in Moore language) is a tree of 5 to $8 \mathrm{~m}$ high, while Ficus sycomorus (kankanga in Moore language) is generally 10 to $30 \mathrm{~m}$ high and about $3 \mathrm{~m}$ in diameter. Their bark is smooth or rough; gray, pink or red. Their latex is white. Both species belong to the genus Ficus (constituting the largest genus in the botanical family Moraceae, with over 1500 species). They are distributed in tropical and subtropical regions of the world and their morphological characteristics vary considerably (Arbonnier, 2000). Previous work relating to Ficus sur and Ficus sycomorus showed antispasmodic and antiplasmodial activities from aqueous extracts of bark and leaves (Sanon et al., 2003; Ayinde et al., 2009). Alkaloids were considered responsible for the antimalarial activity of Ficus sycomorus (Sandabe et al., 2006). However, neither of these species was further studied for its potential in the treatment of associated disorders of sickle cell disease. We then undertook this study with the aim to investigate the antioxidant and antibacterial activities of aqueous extracts of leaves of both Ficus species.

\section{MATERIALS AND METHODS \\ Materials \\ Culture media and microorganisms}

Broth and Mueller Hinton agar were used for antibacterial tests. Strains of Staphylococcus aureus, Escherichia coli and Salmonella typhi were obtained from Children's Hospital and the National Public Health laboratory at Ouagadougou. These wild strains were isolated from urine, feces and blood. In addition, the following American Type Culture Collection (ATCC) reference strains were provided by the same laboratories: Staphylococcus aureus ATCC 6538, Escherichia coli ATCC 25932 and Salmonella typhimurium ATCC 13311.

\section{Plant material}

The leafy stems of Ficus sycomorus were harvested in Tanghin situated on the outskirts of Ouagadougou, in July 2009. Those of the Ficus sur were harvested in August 2009 at Pabré, located at $25 \mathrm{~km}$ from Ouagadougou. After identification by Professor Millogo J., botanist, specimens have been deposited in the herbarium of the University of Ouagadougou, under registration number 01/2009 and 02/2009, respectively for Ficus sycomorus and Ficus sur. 


\section{Extraction and phytochemical screening of extracts}

The leaves of both species were washed, dried away from sunlight for two weeks and then finely ground. 25 grams of powdered leaves of each species were used to perform successive extractions in a Soxhlet system with solvents of increasing polarity (chloroform, ethanol $90 \%$, distilled water). Phytochemical screening was performed by following the method described by Ciulei (1982) for tube tests, and according to the method described par Wagner et al. (1996) for thin layer chromatography (TLC) on silica gel plates $60 \mathrm{~F}_{254}$ (Merck ). Eluent systems (nBuOHsec:MeOH:AcOOH:H2O,

50:6.25:6.25:17.5) and (n-hexane: toluene: ethyl acetate, 6:2:2) were used for the migration of flavonoids, phenolic acids, sterols and triterpens. Phenolic acids and flavonoids were revealed on TLC plates with Neu's reagent in the presence of UV light (365 $\mathrm{nm})$. Sterols and triterpenes were revealed by $3 \% \mathrm{H}_{2} \mathrm{SO}_{4}$ in $\mathrm{EtOH}(96 \%)$.

Estimation of total amount of phenolic compounds, flavonoids, flavonols and tannins

$25 \mathrm{~g}$ of the drug powder were introduced into a $500 \mathrm{~mL}$-flask. $250 \mathrm{~mL}$ of distilled water was added and the mixture was heated to reflux for $30 \mathrm{~min}$. The solution was left to cool at room temperature, then filtered and centrifuged (Centriguge OSI, Italy) for 10 min at $2000 \mathrm{~g}$. The extract obtained was frozen, and then lyophilized for phenolic compound contents determination and biological activities assessment. The latex of Ficus sycomorus was collected from unripe fruits.

\section{Determination of total phenolic content}

Total phenolic content was determined by the method of Singleton et al. (1999). The reaction mixture consists of $1 \mathrm{~mL}$ of extract, 1 $\mathrm{mL}$ of FCR (Folin Ciocalteu Reagent) $2 \mathrm{~N}$ and $3 \mathrm{~mL}$ of a $20 \%$ sodium carbonate solution. This mixture is left to stand at room temperature for $40 \mathrm{~min}$ and then the absorbance was measured (spectrophotometer Agilent 8453) at $760 \mathrm{~nm}$. In the control tube, the extract volume was replaced by distilled water. A standard curve was plotted using tannic acid (1-5 $\mu \mathrm{g} / \mathrm{mL})$. Tests were performed in triplicate. Total phenolic content of the extract was calculated using the formula:

$T_{P T}=\frac{C_{\text {Tube }}}{C_{i}} \times D$

where $\mathrm{T}_{\mathrm{PT}}$ is the total phenolic content of the extract expressed as tannic acid equivalent (mg TAE)/g, $\quad \mathrm{C}_{\text {Tube }}$ is the concentration $(\mathrm{mg} / \mathrm{mL})$ in the test tube, $\mathrm{D}$ the dilution factor and $\mathrm{C}_{\mathrm{i}}$ the concentration in $\mathrm{mg} / \mathrm{mL}$ in the stock solution.

\section{Determination of tannin content}

Tannin content was assessed as described by Tibiri et al. (2007): Polyvinyl polypyrrolidone (PVPP) can precipitate tannins by formation of a complex; $100 \mathrm{mg}$ of PVPP can complex $2 \mathrm{mg}$ of total phenolics. To $1 \mathrm{~mL}$ of extract $(0.50 \mathrm{mg} / \mathrm{mL})$, is added the quantity of PVPP to complex the total phenolics present in the extract (and determined as described above). The mixture was vortexed, kept at $4^{\circ} \mathrm{C}$ for $15 \mathrm{~min}$ and then centrifuged at $3000 \mathrm{~g}$ for $10 \mathrm{~min}$. The supernatant contains phenolic compounds other than tannins (which have been precipitated by PVPP). A test tube was performed like for total phenolics. After 40 minutes, it was centrifuged and the absorbance of the supernatant was measured at $760 \mathrm{~nm}$. Total phenolic content of the supernatant is given by the above formula. Tannin content was determined as the difference between the first value of total phenolics (containing tannins) and the second value of total phenolics (in the absence of tannins)

\section{Determination of flavonoid content}

Flavonoid content was determined as described by Abdel-Hameed (2009). $100 \mu \mathrm{L}$ of extract $(10 \mathrm{mg} / \mathrm{mL})$ in methanol were mixed with $100 \mu \mathrm{L}$ of $20 \%$ aluminum trichloride in methanol and a drop of acetic 
acid, and then the volume was adjusted to 5 $\mathrm{mL}$ with methanol. After $40 \mathrm{~min}$, the absorbance was recorded at $415 \mathrm{~nm}$ (with a spectrophotometer Agilent 8453). Blank consists of $100 \mu \mathrm{L}$ of extract, a drop of acetic acid and adjusted to $5 \mathrm{~mL}$ with methanol. The absorbance of quercetin $(0.10 \mathrm{mg} / \mathrm{mL})$, used as reference compound, is measured under the same conditions. The tests were performed in triplicate. The flavonoids content expressed as quercetin equivalent $(\mathrm{QE})$ is calculated using the following formula:

$T_{\text {Flav }}=\frac{A \cdot m_{0}}{A_{0} \cdot m}$

$\mathrm{T}_{\text {Flav }}$ is the flavonoid content of extract in $\mathrm{mg} \mathrm{QE} / \mathrm{mg} ; A$, the absorbance of the extract; $A_{0}$ the absorbance of quercetin; $m$ the mass in $\mathrm{mg}$ of the extract and $m_{0}$ the mass of quercetin in $\mathrm{mg}$.

\section{Determination of flavonol content}

The flavonol content was determined as described by Abdel-Hameed (2009) using quercetin as reference compound. The dosage is based on the formation of a complex with maximum absorption at $440 \mathrm{~nm} .1 \mathrm{~mL}$ of methanol extract $(10 \mathrm{mg} / \mathrm{mL})$ was mixed with $1 \mathrm{~mL}$ of aluminum trichloride $(20 \mathrm{mg} / \mathrm{mL})$ and $3 \mathrm{~mL}$ of sodium acetate $(50 \mathrm{mg} / \mathrm{mL})$. The absorption was measured after $2 \mathrm{~h} 30 \mathrm{~min}$. The absorbance of quercetin $(0.025 \mathrm{mg} / \mathrm{mL}$ in methanol) was measured under the same conditions. The tests were performed in triplicate. The content of flavonols in the extract (expressed as quercetin equivalent, QE) is calculated using the same formula as for the flavonoids determination (above).

\section{Antiradical and antibacterial activities Antiradical activity by the 1,1-diphenyl-2- picrylhydrazyl (DPPH) test}

The antiradical activity by DPPH test was evaluated using the method described by Kim et al. (2003). The freeze-dried leaves extract was prepared with an initial concentration of $21 \mathrm{mg} / \mathrm{mL}$ in dimethyl sulfoxide (DMSO). Concentrations range of extracts or standard (quercetin) was prepared by successive dilution using microplate technique. The absorbance of residual DPPH in each well was measured at $490 \mathrm{~nm}$ (with a spectrophotometer BIO-RAD Model 680) after incubation at $37^{\circ} \mathrm{C}$ for $30 \mathrm{~min}$. The antiradical activity of a sample (calculated by the following formula) is given as percentage of reduced DPPH:

$I \%=\frac{A_{0}-A_{s}}{A_{0}} \times 100 ;$ where $\mathrm{I}$ is the percentage of inhibition, $\mathrm{A}_{0}$ absorbance of control, As the absorbance of the sample. For each sample, the concentration (in $\mu \mathrm{g} / \mathrm{mL}$ ) required to reduce by $50 \%$ the activity of DPPH $\left(\mathrm{IC}_{50}\right.$ was determined.

\section{Antibacterial activity}

The antibacterial activity was evaluated using the method of diffusion through agar as described by Perez et al. (1990). It consists of determining the Minimum Inhibitory Concentration (MIC) which is the lowest concentration of an extract or an antibiotic which does not allow a visible growth (when looking the media with naked eye) (Karaman et al., 2003). The larger the zone of inhibition, the greater the extract is active. The lyophilized decoction of leaves was prepared at a concentration of $10 \mathrm{mg} / \mathrm{mL}$ from which different twofold dilutions were prepared. 1 $\mathrm{mL}$ of latex was introduced into a sterile tube (whose weight was initially determined) and evaporated to dryness. $10 \mathrm{~mL}$ of distilled water were added to the tube and vortexed to dissolve the latex. From this extract (16 $\mathrm{mg} / \mathrm{mL}$ ), twofold dilutions were prepared. The reference controls, gentamicin $(10 \mu \mathrm{g} / \mathrm{disc})$ and ampicillin $(10 \mu \mathrm{g} / \mathrm{disk})$ were tested in parallel.

\section{Analysis and expression of results}

The results are expressed as mean \pm SEM $(n=3)$. The Data were analyzed using ANOVA followed by Dunnett's posttest for multiple comparisons using Graph Pad Prism version 5.0 for Windows, Graph Pad Software, San Diego California United States. Differences were considered statistically 
significant for a $p$-value less than or equal to 0.05 .

\section{RESULTS}

Phytochemical profile of extracts

In the present investigation, preliminary phytochemical screening, using tube tests and TLC was performed on leaf extracts of both species. This analysis showed the presence of phytochemical constituents including alkaloids, carbohydrates, flavonoids, saponins, steroids, tannins, phenols, triterpenoids, anthracenosides, anthocyanins, and coumarins (Table 1). Similar results were obtained with extracts of bark of Ficus racemosa (Poongothai et al., 2011). These results show a wealth of both species extracts in key phytochemicals.

\section{Antioxidant activity and phenolic content}

DPPH scavenging activities of all the extracts were concentration dependent (Table 2). However, the highest DPPH scavenging activity was shown by the extract from Ficus sycomorus $\left(9.60 \pm 0.02 \mu \mathrm{g} / \mathrm{mL}, \mathrm{IC}_{50}\right)$. Both extracts showed a weak activity as compared to those of Quercetin $(4.60 \pm 0.08 \mu \mathrm{g} / \mathrm{mL}$, $\mathrm{IC}_{50}$ ) which is a reference antioxidant.

Phenolic compounds are very important plant constituents because they exhibit antioxidant activity by inactivating free radicals or prevent decomposition of hydroperoxides into free radicals (Pokorny et al., 2001). The total phenolic, tannin, flavonoid, and flavonol content of the two extracts were determined in this study (Table 2 ). The concentration of phenolic compounds, tannins, and flavonoids were higher in the extract from Ficus sycomorus when compared with the same extract from Ficus sur. For flavonol content, Ficus sur $(0.27 \pm 0.01 \mathrm{mg}$ $\mathrm{QE} / \mathrm{g})$ is richer than Ficus sycomorus $(0.23 \pm$ $0.00 \mathrm{mg} \mathrm{QE} / \mathrm{g}$ ).

\section{Antibacterial activity}

The results of the antibacterial assay of the leaves extracts of both Ficus species and the latex of Ficus sycomorus are presented in Table 3. Of the three extracts tested, the latex

Table 1: Chemical composition of leaf extracts of Ficus sur and Ficus sycomorus.

\begin{tabular}{lcc}
\hline Chemical groups & Plants & \\
\cline { 2 - 3 } & Ficus sur Forsk. & Ficus sycomorus L. \\
\hline Sterols and triterpenes & + & + \\
Carotenoïds & + & + \\
Alkaloid bases & - & - \\
Flavones aglycones & - & - \\
Anthracenosids aglycones & - & - \\
Coumarins & - & - \\
Tannins & + & + \\
Alkaloid salts & + & + \\
Reducing compounds & + & + \\
Flavonosides & + & + \\
Anthracenosides & + & + \\
Coumarin derivatives & + & + \\
Cardenolides & + & + \\
Anthocyanins & + & + \\
Saponins & + & + \\
\hline+ present, - absent & &
\end{tabular}


Table 2: Phenolic contents of leaf aqueous extracts and scavenging activity by the DPPH test.

\begin{tabular}{llllll}
\hline & $\begin{array}{l}\text { Total } \\
\text { phenolic } \\
\text { mg TAE/g }\end{array}$ & $\begin{array}{l}\text { Tannins } \\
\text { mg TAE/g }\end{array}$ & $\begin{array}{l}\text { Flavonoids } \\
\text { mg QE/g of }\end{array}$ & $\begin{array}{l}\text { Flavonols } \\
\text { mg QE/g }\end{array}$ & $\begin{array}{l}\text { Antiradical } \\
\text { activity } \\
\text { against DPPH } \\
\text { IC }_{\mathbf{5 0}}(\boldsymbol{\mu g} / \mathbf{m l})\end{array}$ \\
\hline Ficus sur & $\begin{array}{l}247,00 \\
\pm 0,52^{\mathrm{a}}\end{array}$ & $120,80 \pm 0,83^{\mathrm{a}}$ & $19,78 \pm 0,16^{\mathrm{a}}$ & $0,27 \pm 0,01^{\mathrm{a}}$ & $31,83 \pm 0,55^{\mathrm{a}, \mathrm{b}}$ \\
& & & & \\
Ficus & 336,80 & $203,74 \pm 0,90$ & $22,37 \pm 0,10$ & $0,23 \pm 0,00$ & $9,60 \pm 0,02^{\mathrm{b}}$ \\
$\begin{array}{l}\text { sycomorus } \\
\text { Quercetin }\end{array}$ & $\pm 0,80$ & & & & $4,60 \pm 0,08$ \\
\hline
\end{tabular}

TAE, Tannic Acid Equivalent; QE, Quercetin Equivalent; values are mean $\pm \mathrm{SEM}(\mathrm{n}=3)$; a, $\mathrm{p}<0,05$ against F. sycomorus; $\mathrm{b}, \mathrm{p}<0,05$ against quercetin

Table 3. MIC values (mg/mL) of leaf aqueous extracts and latex of Ficus sycomorus against various bacterial strains.

\begin{tabular}{ccccccc}
\hline \multirow{2}{*}{ Plant } & \multicolumn{9}{c}{ Bacteria } \\
\cline { 2 - 6 } & S. aureus & S. aureus ATCC & E. coli & $\begin{array}{c}\text { E.coli } \\
\text { ATCC }\end{array}$ & $\begin{array}{c}\text { Sa. } \\
\text { typhi }\end{array}$ & $\begin{array}{c}\text { Sa.typhi } \\
\text { ATCC }\end{array}$ \\
\cline { 2 - 6 } Ficus sur & 2.50 & 1.25 & 2.50 & 2.50 & - & - \\
Ficus sycomorus & 0.31 & 0.31 & 0.63 & 0.63 & - & - \\
Latex (Ficus & 0.13 & 0.13 & 0.25 & 0.25 & - & - \\
sycomorus) & & & & & - \\
\hline Staphylococcus aureus (S. aureus), Escherichia coli (E. coli), Salmonella typhimurium (Sa. typhi); - no activity;
\end{tabular}

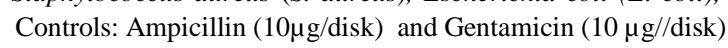

of Ficus sycomorus was the most potent because it has the best minimum inhibitory concentration (MIC) on Staphylococcus aureus (MIC of $0.13 \mathrm{mg} / \mathrm{mL}$ ) and Escherichia coli (MIC of $0.25 \mathrm{mg} / \mathrm{mL}$ ). The best antibacterial activity of the three extracts was against Staphylococcus aureus ATCC. Furthermore, none extract had any inhibition activity against Salmonella typhimurium.

\section{DISCUSSION}

Herbal extracts contain different phytochemicals with biological activity that can be of valuable therapeutic index. Much of the therapeutic effects of medicinal plants species have been attributed to phytochemicals, which are the non-nutrient plant compounds. The major phytochemicals revealed by the screening are known to possess a wide range of activities, which may help in protection against chronic diseases. For example saponins, flavonoids, tannins and alkaloids have hypoglycemic and antiinflammatory activities (Augusti et al., 2008). Reports show that saponins possess hypocholesterolemic and antidiabetic properties (Rupasinghe et al., 2003). The terpenoids have also been shown to decrease blood sugar level in animal studies. Steroids, triterpenoids and saponins showed analgesic properties and central nervous system activities (Argal et al., 2006). Moreover, the results of this phytochemical screening could support the use of the two species in traditional medicine for the treatment of sickle cell disease. Indeed, many works report the effectiveness of plant secondary metabolites in the treatment of this pathology. Several research results indicate that phenolic compounds and anthocyanins play a role in 
the anti-sickle cell activities of some medicinal plants (Mpiana et al., 2008; Ouattara et al., 2009). The detection of phenolics and anthocyanins in extracts of both species indicates a potential of interesting phytochemicals recognized as active against sickle cell disease.

The results also showed that the antiradical scavenging activity is related to the amount of the phenolic content. Then, Ficus sycomorus which had the highest total phenolic content with $336.80 \pm 0.80 \mathrm{mg}$ TAE/g had also the best antiradical activity with an $\mathrm{IC}_{50}$ of $9.6 \pm 0.02 \mathrm{mg} / \mathrm{mL}$. Compared to the antiradical activity of the reference control, quercetin $\left(\mathrm{IC}_{50}=4.6 \pm 0.08 \mathrm{~g} / \mathrm{ml}\right.$ ), this result, obtained from a raw extract, shows a significant scavenging activity of the active chemicals in leave extract of Ficus sycomorus. Previous studies reported the antioxidant activity of some species of Ficus and also showed that this antioxidant activity is related to the phenolic content (Al-Fatimi et al., 2007; Abdel-Hameed, 2009). The antiradical activity of Ficus sur and Ficus sycomorus could be due to the high content of tannins and flavonoids in the leaves of both species. Flavonoids have important antioxidant and antiradical activities. Their protective effects in biological systems are linked to their ability to transfer electrons to free radicals, chelate metals, activate antioxidant enzymes, reducing radicals of alpha-tocopherol or to inhibit oxidases (Bruneton, 2009). Also, the effects of hypoxia are partially mitigated in response to treatment with antioxidants (Carriere et al., 2004). Bouchet et al. (1998) showed that hydrolysable or condensed tannins have antiradical and antioxidant properties expressed by their inhibiting effect on lipid peroxidation (induced by $\mathrm{Fe}^{2+}$ ) and radical-scavenging ability on DPPH radical. In addition to the molecular abnormality that governs the synthesis of abnormal $S$ hemoglobin, sickle cell anemia is one of the conditions in which the production of free radicals results in a state of oxidative stress. It was also showed that the excessive production of superoxide anions and hydroxyl radicals in erythrocytes, resulting from the instability of $\mathrm{S}$ hemoglobin, can be the initiating factor of hemolysis, which releases in the plasma ionized iron and heme molecules generating in turn, free radicals Deby et al. (1986). Our results show that Ficus sycomorus and Ficus sur could be of interest in finding news molecules with antioxidant activity because of their high content in phenolics compounds.

About antibacterial properties, the interesting activity of latex is corroborated by other reports showing that the latex of Ficus carica $\mathrm{L}$. is more active than leaf extracts on yeast and human pathogenic bacteria (Aref et al., 2010). Evaluation of the antibacterial activity of the two species is important because in addition to the painful crises and anemia, infections are recurrent pathologies of the sickle cell disease that slow down blood circulation. Infectious complications remain the leading cause of death among sickle cell children patients. Indeed meningitis, septicemia and osteomyelitis are common infections in these patients. Salmonella typhi and Staphylococcus aureus are the bacteria most implicated in septicemia and osteomyelitis (Diagne et al., 2003), while some serotypes of Escherichia coli (K1 in particular) are able of causing very serious neonatal infections that are potentially complicated by meningitis septicemia (Sansonetti, 1985). Several works reported antibacterial activities of phenolic compounds such as tannins (Kolodzeij et al., 1999). The occurrence of phenolic compounds in both species of Ficus could support the observed antibacterial activity.

\section{Conclusion}

This study showed that the antiradical and antibacterial activity of Ficus sur and Ficus sycomorus extract can provide scientific support of their traditional use in the treatment of sickle cell disease. The highest content in total phenolics and tannins and the best antiradical activity were obtained with Ficus sycomorus. In addition, the latex of this plant 
showed an antibacterial activity on some very important pathogenic germs related to sickle cell disease. Theses preliminary results call for further investigations of this plant, using biological models of sickle cell disease.

\section{REFERCENCES}

Abdel-Hameed E-SS. 2009. Total phenolic contents and free radical scavenging activity of certain Egyptian Ficus species leaf samples. Food Chem., 114(4): 12711277.

Al-Fatimi M, Wurster M, Schroder G, Lindequist U. 2007. Antioxidant, antimicrobial and cytotoxic activities of selected medicinal plants from Yemen. $J$. Ethnopharmacol., 111(3): 657-666.

Arbonnier M. 2000. Arbres, arbustes et lianes des zones sèches d'Afrique de l'Ouest. CIRAD-MNHN: Montpellier-Paris.

Aref HL, Salah KB, Chaumont JP, Fekih A, Aouni M, Said K. 2010. In vitro antimicrobial activity of four Ficus carica latex fractions against resistant human pathogens (antimicrobial activity of Ficus carica latex). Pak J Pharm Sci., 23(1): 53-58.

Argal A, Pathak AK. 2006. CNS activity of Calotropis gigantea roots. J. Ethnopharmacol., 106(1): 142-145.

Augusti KT, Cherian S. 2008. Insulin sparing action of leucopelargonidin derivative isolated from Ficus bengalesis Linn. Indian J. Exp. Biol., 33: 608-611.

Ayinde BA, Owolabi OJ. 2009. Effects of the aqueous extract of Ficus capensis Thunb. (Moraceae) leaf on gastrointestinal motility. J. Pharmacognosy Phytother., 1(3): 031-035.

Bouchet N, Barrier L, Fauconneau B. 1998. Radical scavenging activity and antioxidant properties of tannins from Guiera senegalensis (Combretaceae). Phytother. Res., 12(3): 159-162.

Bruneton J. 2009. Pharmacognosie, Phytochimie, Plantes médicinales (4th edn). Lavoisier Tec \& Doc: Paris.
Carriere A, Carmona MC, Fernandez Y, Rigoulet M, Wenger RH, Penicaud L, Casteilla L. 2004. Mitochondrial reactive oxygen species control the transcription factor CHOP-10/GADD153 and adipocyte differentiation: a mechanism for hypoxia-dependent effect. J. Biol. Chem., 279(39): 40462-40469.

CID. 2010. Comité d'Initiative contre la Drépanocytose: Informations sur la drépanocytose. http://absantep.org/spip. php?article48 (Acceded on 29 juin 2011).

Ciulei I. 1982. Methodology for analysis of vegetable drug. Pratical manual on industrial utilization of medicinal and aromatic plants. Ministry of Chemical Industrie, Bucharest.

Deby C, Pincemail J. 1986. [Toxicity of oxygen, free radicals and defense mechanisms]. Presse Med., 15(31): 14681474.

Diagne I, Diagne-Gueye ND, Signate-Sy H, Camara B, Lopez-Sall P, Diack-Mbaye A, Sarr M, Ba M, Sow HD, Kuakuvi N. 2003. Management of children with sickle cell disease in Africa: experience in a cohort of children at the Royal Albert Hospital in Dakar. Med. Trop., 63(4-5): 513-520.

Girot R, Bégué P, Galacteros F. 2003. La Drépanocytose. John Libbey \& Co: Paris.

Karaman I, Sahin F, Gulluce M, Ogutcu H, Sengul M, Adiguzel A. 2003. Antimicrobial activity of aqueous and methanol extracts of Juniperus oxycedrus L. J. Ethnopharmacol., 85(2-3): 231-235.

Kim KS, Lee S, Lee YS, Jung SH, Park Y, Shin KH, Kim BK. 2003. Anti-oxidant activities of the extracts from the herbs of Artemisia apiacea. J. Ethnopharmacol., 85(1): 69-72.

Kolodzeij H, Kayser O, Latte KP, Ferreira D. 1999. Evaluation of the antimicrobial potency of tannins and related compounds using the microdilution broth method. Planta Med., 65(5): 444-446.

Mpiana PT, Mudogo V, Tshibangu DS, Kitwa EK, Kanangila AB, Lumbu JB, Ngbolua 
KN, Atibu EK, Kakule MK. 2008. Antisickling activity of anthocyanins from Bombax pentadrum, Ficus capensis and Ziziphus mucronata: photodegradation effect. J. Ethnopharmacol., 120(3): 413-418.

Ouattara B, Jansen O, Angenot L, Guissou IP, Frederich M, Fondu P, Tits M. 2009. Antisickling properties of divanilloylquinic acids isolated from Fagara zanthoxyloides Lam. (Rutaceae). Phytomedicine, 16(2-3): 125-129.

Perez C, Pauli MH, Bazerque P. 1990. An antibiotic assay by the agar-well diffusion method. Acta. Biol. Med. Exp., 15: 113-115.

Pokorny J, Yanishlieva N, Gordon NH. 2001. Antioxidant in Foods Practical Applications ( $1^{\text {st }}$ edn). CRC Press: Cambridge.

Poongothai A, Sreena KP, Sreejith K, Uthiralingam M, Annapoorani S. 2011. Preliminary phytochemicals screening of Ficus racemosa Linn. bark. Int J Pharm. BioSci., 2(2): 431434.

Rupasinghe HP, Jackson CJ, Poysa V, Di Berardo C, Bewley JD, Jenkinson J. 2003. Soyasapogenol A and B distribution in soybean (Glycine max L. Merr.) in relation to seed physiology, genetic variability, and growing location. J. Agric. Food Chem., 51(20): 5888-5894.

Sandabe UK, Onyeyili PA, Chibuzo GA. 2006. Phytochemical screening and effect of aqueous extract of Ficus sycomorus L. (Moraceae) stem bark on muscular activity in laboratory animals. $J$. Ethnopharmacol., 104(1-2): 283-285.
Sanon S, Ollivier E, Azas N, Mahiou V, Gasquet M, Ouattara CT, Nebie I, Traore AS, Esposito F, Balansard G, TimonDavid P, Fumoux F. 2003. Ethnobotanical survey and in vitro antiplasmodial activity of plants used in traditional medicine in Burkina Faso. $J$. Ethnopharmacol., 86(2-3): 143-147.

Sansonetti PJ. 1985. E. coli entéropathogènes: données récentes sur la virulence. Bull. Inst. Pasteur, 83: 5-18.

Schmugge M, Speer O, Ozsahin AH, Martin G. 2008. La drépanocytose en Suisse, $1^{\mathrm{er}}$ partie: Physiopathologie, clinique. Forum Med Suisse, 8(33): 582-586.

Sess ED, Carbonneau MA, Meite M, Peuchant E, Dumont MF, Receveur MC, Thomas MJ, Perromat A, Sangare A, Le Bras M, Clerc M. 1998. Markers of lipid peroxidation, inflammatory proteins and plasma tocopherols in homozygotic and heterozygotic sickle cell anemia. Bull. Soc. Pathol. Exot., 91(3): 238-241.

Singleton VL, Orthofer R, Lamuela-Raventós RM. 1999. Analysis of total phenols and other oxidation substrates and antioxidants by means of folin-ciocalteu reagent. In Methods Enzymol. Lester P (ed). Academic Press; 152-178.

Tibiri A, Rakotonandrasana O, Nacoulma GO, Banzouzi JT. 2007. Radical Scavenging Activity, Phenolic Content and Cytotoxicity of Entada africana Guill. et Perr. (Mimosaceae). J. Biol. Sci., 7(6): 959-963.

Wagner H, Bladt S. 1996. Plant Drug Analysis: a Thin Layer Chromatography Atlas ( $2^{\text {nd }}$ edn). Springer: New York. 